\title{
Early Holocene Openlands in Southern New England
}

\section{Citation}

Faison, E. K., Foster, D. R., Oswald, W. W., Doughty, E. D., Hansen, B. C. S. 2006. Early Holocene openlands in southern New England. Ecology 87: 2537-2547.

\section{Published Version}

10.1890/0012-9658(2006)87[2537:EHOISN]2.0.C0;2

\section{Permanent link}

http://nrs.harvard.edu/urn-3:HUL.InstRepos:30700137

\section{Terms of Use}

This article was downloaded from Harvard University's DASH repository, and is made available under the terms and conditions applicable to Other Posted Material, as set forth at http:// nrs.harvard.edu/urn-3:HUL.InstRepos:dash.current.terms-of-use\#LAA

\section{Share Your Story}

The Harvard community has made this article openly available.

Please share how this access benefits you. Submit a story.

Accessibility 


\title{
EARLY HOLOCENE OPENLANDS IN SOUTHERN NEW ENGLAND
}

\author{
E. K. Faison, ${ }^{1,3}$ D. R. Foster,${ }^{1}$ W. W. Oswald, ${ }^{1}$ B. C. S. Hansen, ${ }^{2}$ and E. Doughty ${ }^{1}$ \\ ${ }^{1}$ Harvard Forest, Harvard University, Petersham, Massachusetts 01366 USA \\ ${ }^{2}$ Limnological Research Center, University of Minnesota, Minneapolis, Minnesota 55455-0219 USA
}

\begin{abstract}
The pre-historical vegetation structure in temperate forest regions is much debated among European and North American ecologists and conservationists. Frans Vera's recent hypothesis that large mammals created mosaics of forest and openland vegetation in both regions throughout the Holocene has been particularly controversial and has provoked new approaches to conservation management. Thirty years earlier, American paleoecologists Herb Wright and Margaret Davis debated whether abundant ragweed pollen at Rogers Lake, Connecticut at $9500 \mathrm{yr}$ BP signified local forest openings or long-distance transport of pollen from Midwestern prairies. Using new pollen records from Harvard Forest and the North American Pollen Database, we address this question and offer insights to the openland discussion. Ragweed and other forbs exceed 3.5\% at five sites in a restricted area of southern New England between 10100 and 7700 yr BP. Strong evidence suggests this pollen originated from the landscapes surrounding these sites (supporting Davis), as ragweed pollen percentages do not increase with longitude from New England to the Midwest. Ragweed pollen percentages are also unrelated to basin size and therefore unrelated to the proportion of extraregional pollen in New England. High forbs values were associated with increases in oak, decreases in white pine, and relatively high charcoal values. Modern pollen records with similar forb and tree percentages occur along the Prairie Peninsula region of the Upper Midwest. However, the closest analogue to the southern New England early Holocene assemblages comes from Massachusetts' Walden Pond in the early 18th century. These results and the affiliation of ragweed for open, disturbed habitats suggest that oak-pine forests with large openings persisted for over 2000 years due to dry conditions and perhaps increased fire frequency. This conclusion is corroborated by independent lake level and climate reconstructions. Because these early Holocene openlands have no detectable analogue in New England for the past 7000 years before European settlement, we suggest that all important openlands today are almost exclusively a legacy of Colonial agriculture and should be managed accordingly. Nonetheless, our results may have implications for forest dynamics accompanying projected climate change to more arid conditions in New England over the next century.

Key words: Ambrosia spp.; climate; early Holocene; fire; forbs; herbivores; Midwest; New England; oak; openlands; paleoecology; ragweed.
\end{abstract}

\section{INTRODUCTION}

To what extent have upland areas in temperate forest regions supported openland (i.e., nonforest, grass-, and shrub-dominated) vegetation during historical and prehistorical times? This question has been long debated by ecologists, conservation biologists, and land managers (cf. Askins 2000, Motzkin and Foster 2002, Svenning 2002). Seminatural openland vegetation is currently uncommon in these forested regions and has declined dramatically in the last century due to agricultural abandonment and intensification, natural succession to forest, and industrial and residential development (Svenning 2002, Foster and Motzkin 2003). Due to this trend and the threatened status of many plant and

Manuscript received 17 October 2005; revised 13 March 2006; accepted 14 March 2006. Corresponding Editor: A. H. Lloyd.

${ }^{3}$ E-mail: faison@fas.harvard.edu animal species in these habitats, openlands are the focus of conservation, restoration, research, and debate (Vickery and Dunwiddie 1997, Foster and Motzkin 2003, Mitchell 2005).

The recent suggestion by Dutch ecologist Frans Vera (2000) that prehistoric landscapes in Europe and eastern North American supported mosaics of open and wooded vegetation, rather than expansive forests, has sparked far-reaching discussion and initiated significant reforms in conservation practices across Europe (Svenning 2002, Bradshaw et al. 2003). Vera (2000) and Askins (2000) posit that large herbivores such as aurochs (Bos taurus), bison (Bison spp.), and mastodons (Mammut americanum) generated disturbances that initiated and perpetuated openlands, park-like woodlands, and regenerating forests. Other researchers suggest that fire and beavers (Castor canadensis) also reduced forest cover (Pyne 1982, Svenning 2002). Acceptance of this interpretation in England, the Netherlands, and some Scandinavian countries has led to a reevaluation of 
conservation policies and management practices (Kirby 2004, Mitchell 2005).

Parallel debate on prehistoric openlands has occurred over the past three decades in the northeastern United States where intensive human disturbance has a shorter history, the current extent of forest is much greater, and openlands are less common (Vickery and Dunwiddie 1997, Foster and Motzkin 2003). Aside from Askins (2000), much of this debate focuses on the past 500-1000 years and the potential for Native American burning, agriculture, and fuelwood collection to reduce forest cover (Cronon 1984, Patterson and Sassamann 1988, Foster et al. 2002).

However, the relatively cool and wet climate during this period supported vigorous and resilient forest cover, and little evidence exists for extensive open vegetation on the uplands (Motzkin and Foster 2002, Foster and Motzkin 2003, Shuman et al. 2004). In contrast, dry conditions prevailed across the eastern United States during the early Holocene (11000-7500 yr BP), when summer insolation was at a peak, and lake levels reached postglacial lows (Berger and Loutre 1991, Shuman et al. 2004). Evaluation of openland assemblages during this period may provide a useful context for contemporary discussions, as well as new insights into regional vegetation history.

Margaret Davis (1969) and Herb Wright (1968) debated the existence of early Holocene openland vegetation in New England after Davis noted a lengthy period with high ragweed (Ambrosia spp.) pollen percentages at Rogers Lake, Connecticut. Davis concluded that: (1) the ragweed grew locally around Rogers Lake, and (2) it resulted from sharply reduced forest density. In contrast, Wright suggested ragweed pollen was an extra-regional signal from the expanding Midwestern prairies. This 35-year-old debate was never resolved (T. Webb and H. E. Wright, personal communication) and is reexamined in light of new data in this paper.

Our study focused on the following questions. Does the early Holocene ragweed period at Rogers Lake represent local conditions or long-distance dispersal? If the former, how geographically broad is it, what vegetation assemblages produced it, what environmental factors controlled its appearance in a forested landscape, and what analogues are there for it? Finally, what insights do these early Holocene pollen assemblages shed on current ecological and conservation debates regarding openlands?

\section{Study Area}

New England has a range of seasonal climates, edaphic conditions, and vegetation resulting from mosaics of bedrock geology and glacial activity overlying temperate, maritime climate gradients and seasonal storm tracks. The region is characterized by northsouth trending mountains and hills and generally narrow valleys (Foster 2004). Expansive uplands rang- ing from 200 to $500 \mathrm{~m}$ elevation and covered by glacial till extend from southern Connecticut northward, flanked by a 5-50 km wide coastal lowland. Cape Cod and the adjoining islands are composed of sandy moraine and outwash modified by coastal processes (Foster 2004). Mean annual temperatures range from $11^{\circ} \mathrm{C}$ along the Connecticut coast to $4^{\circ} \mathrm{C}$ in northern New England. Mean precipitation ranges from 88 to 125 $\mathrm{cm}$ (Foster 2004). Disturbances, including fire and hurricanes, follow a southeast to northwest gradient of decreasing frequency and intensity, whereas ice storms affect the northern region more severely (Boose et al. 2001, Parshall and Foster 2002).

Forests in northern New England and the mountains are characterized by balsam fir (Abies balsamea), red spruce (Picea rubens), yellow and paper birch (Betula alleghaniensis and B. papyrifera), beech (Fagus grandifolia), and sugar maple (Acer saccharum) (Fig. 1). At lower elevations white pine (Pinus strobus) and eastern hemlock (Tsuga canadensis) occur with northern hardwoods, whereas in the transitional area across central Massachusetts, oaks (Quercus spp.), hickories (Carya spp.), and red maple (Acer rubrum) dominate with northern hardwoods, white pine, and hemlock. Hemlock, white pine, oaks, hickories, red maple, and black birch (Betula lenta) characterize the forests of southern and eastern Massachusetts and northern Connecticut and Rhode Island. White pine decreases in southern Connecticut and Rhode Island, while pitch pine (Pinus rigida) and oak dominate on Cape Cod and the islands. (Foster 2004). At European settlement New England was heavily forested, with open areas restricted to wetlands, water bodies, and frequently used Native American sites (Patterson and Backman 1988, Cogbill et al. 2002). With the exception of some coastal islands, herb, shrub, and graminoid pollen values were extremely low (Foster and Motzkin 2003). The landscape changed dramatically following European settlement, with forest clearance for agriculture peaking in the mid-19th century. Reforestation following the abandonment of farms in the late 19th century led to the current situation in which forest cover across New England ranges from 60 to $90 \%$ (Foster 2004).

\section{Methods}

To interpret the early Holocene ragweed maximum at Rogers Lake, we examined paleoecological records from the Harvard Forest (HF) archives (available online) ${ }^{4}$ and the North American Pollen Database (NAPD; available online $)^{5}$ for sites in New England, New York, Pennsylvania, Ohio, and Indiana. We restricted our analysis to sites with data for the past 11000 years and sampling resolutions of $\leq 500$ years between 10500 and $7500 \mathrm{yr}$ BP. Forty-five sites across the nine-state region met

\footnotetext{
$4\langle$ http://harvardforest.fas.harvard.edu/data.html $\rangle$

5 http://www.ncdc.noaa.gov/paleo/ftp-pollen.html $\rangle$
} 
A
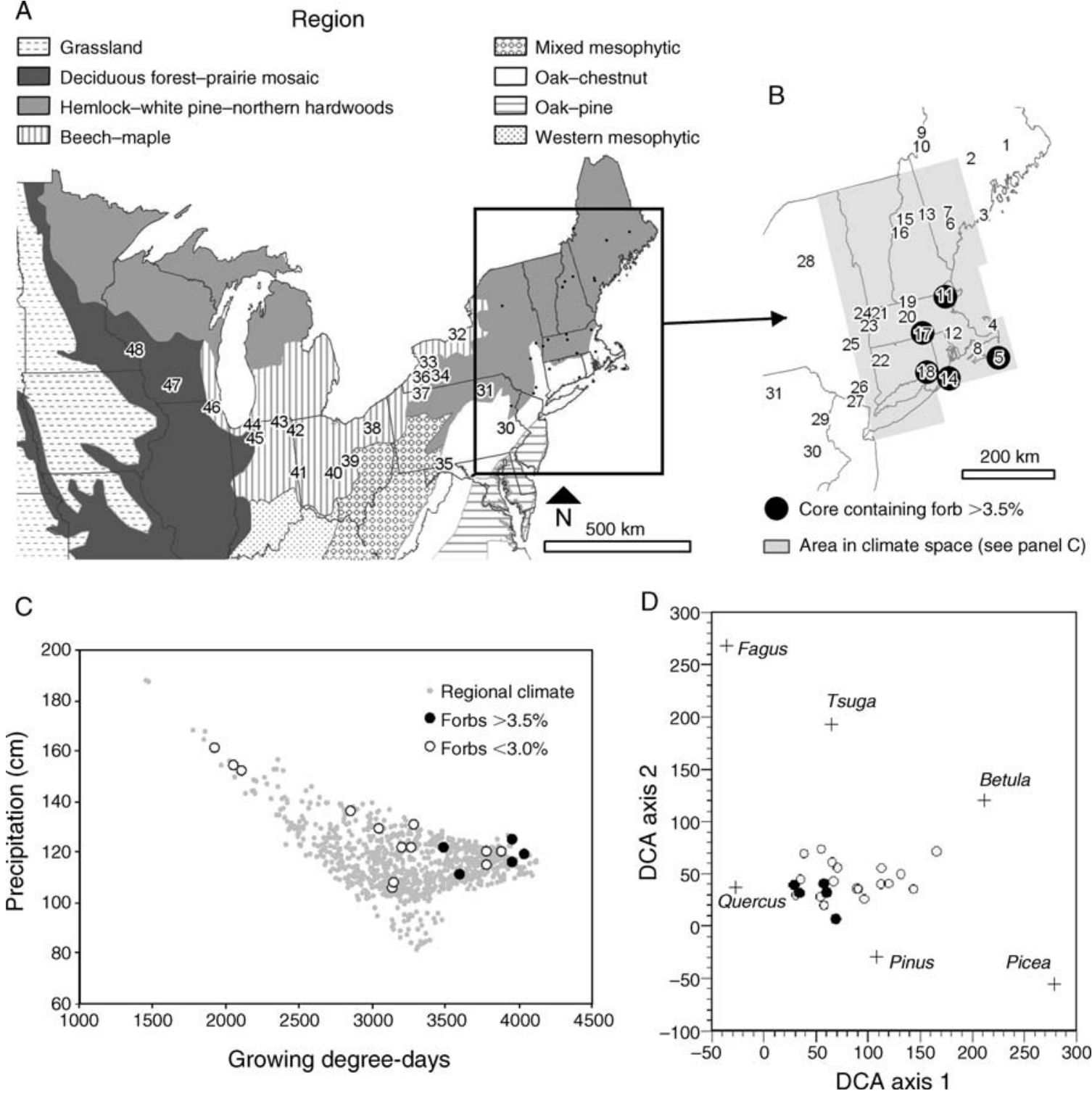

FIG. 1. (A) Location of all sites used in analyses. The map is adapted from Braun (1950) and Davis (1983). See the Appendix for site names. (B) Map of study sites in New England. Black circles indicate sites with early Holocene forb pollen $>3.5 \%$. Shading shows the area for which modern climate is plotted in panel C. (C) Modern precipitation and growing degree-days for New England study sites. (D) Detrended correspondence analysis of major tree taxa and New England paleoecological records. Relative percentages of Fagus, Tsuga, Betula, Quercus, Pinus, and Picea pollen are included in axis 1 and axis 2. Circles are centroids of samples for each site between 10500 and $7500 \mathrm{yr}$ BP. Solid circles represent the following five southern New England forb sites (with site number in parentheses): No Bottom Pond (5), Berry East Pond (11), Fresh Pond (14), Blood Pond (17), and Rogers Lake (18).

these criteria, including 5 from $\mathrm{HF}$ and 41 from the NAPD (Fig. 1A, B).

For each early Holocene record, we noted strata where the total pollen of four openland forb taxa (ragweed, other asters [Asteraceae spp.], goosefoot/ amaranth [Chenopodiaceae/Amaranthaceae], and wormwood [Artemisia spp.]) exceeded 3.5\%. This threshold was based on the peak value reported by Davis (1969) at Rogers Lake of 3.8\% (3.3\% ragweed). Grass (Poaceae spp.) and sedge (Cyperaceae spp.) were excluded because they occur abundantly in wetlands (Webb et al. 1983).

Detrended correspondence analysis (DCA) of major tree taxa (beech, birch, pine, oak, spruce, and hemlock) was used to analyze and compare the arboreal composition among New England sites at 10 500-7500 yr BP. Similarities between early Holocene pollen assemblages of southern New England and modern assemblages from the Midwest and southern New England were evaluated using squared-chord distance (SCD) analyses 
of major tree, shrub, and forb taxa including alder (Alnus spp.), ash (Fraxinus spp.), aster, beech, birch, elm (Ulmus spp.), goosefoot/amaranth, grass, hazelnut (Corylus spp.), hemlock, hickory, ironwoods (Ostrya/ Carpinus), maple, oak, pine, ragweed, sedge, spruce, sycamore (Platanus spp.), walnut (Juglans spp.), and wormwood (Overpeck et al. 1985).

Charcoal and loss-on-ignition (LOI) data were available for the HF but not the NAPD sites. Charcoal data were obtained by counting "microscopic" charcoal fragments encountered along transects on the same slides used for pollen analysis. Only pieces $>10 \mu \mathrm{m}$ were measured, as small fragments are difficult to distinguish from opaque mineral grains. Marker grains encountered along the transects were also counted. We express the abundance of charcoal of this size fraction as influx values (square millimeters per square centimeter per year). Specific information on the coring, chronology, LOI, and pollen of HF sites can be found in W. W. Oswald, E. K. Faison, D. R. Foster, and B. C. S. Hansen (unpublished manuscript).

\section{RESULTS}

Five New England sites had at least one level with $\geq 3.5 \%$ forb pollen during the early Holocene (Fig. 1B): Rogers Lake, Connecticut (Davis 1969); Fresh Pond, Rhode Island (Dunwiddie 1990); Blood, Berry East, and No Bottom Ponds, Massachusetts (Dunwiddie 1990). Ragweed is the major forb at four sites, while other asters dominate at No Bottom Pond.

\section{Resolving the question of local vs. extra-regional sources of ragweed pollen}

To determine whether ragweed and other forb pollen came from local or extra-regional sources we analyzed the pollen data according to four criteria and obtained the following results.

If ragweed pollen originated in the Midwest, we would expect that:

1. Percentages would decrease with distance from Illinois, the closest area with abundant ragweed pollen (18\%) during the early Holocene (King 1981).--This hypothesis was not confirmed; longitude is unrelated to maximum percentages of ragweed for the period 10500 $7500 \mathrm{yr}$ BP. High percentages occur in Ohio and Indiana and at a few New England sites, but low values are recorded in New York and Pennsylvania and most of New England (data not shown).

2. Ragweed percentages will increase with increasing basin size (and inputs of extra-regional pollen [Sugita 1993]) in New England.-This hypothesis was not confirmed; basin size is unrelated to maximum percentages of ragweed (data not shown).

If ragweed and other asters were locally present in New England, we would expect that their abundance would relate to specific environmental or biotic features in a coherent geographical area. Therefore, for the five sites with $\geq 3.5 \%$ forb pollen we examined the following.
1. Similarity in modern climatic space (i.e., moisture and temperature regime).- -The five sites occur in southeastern New England and share a similar warm and dry climate today, relative to northwestern Massachusetts, New Hampshire, and Maine. (Fig. 1C). Although New England's modern climate is a poor analogue to its early Holocene climate, the relative moisture and temperature gradients, driven largely by latitude and elevation, would probably have been similar between the two time periods. Lower sea levels during the early Holocene would probably have amplified this climatic gradient by reducing the moderating influence of the ocean.

2. Similarity in vegetation composition.-The five sites have a similar oak-pine pollen assemblage during the early Holocene that is distinct from all but three other regional sites (Fig. 1D). This pattern supports the above notion of a consistent climatic gradient over time, as the Northern sites have pollen assemblages with more cool, moist-tolerant hemlock, beech, and spruce.

\section{Timing and environmental context of forb period}

The rise in forb pollen percentages above $3.5 \%$ occurs first at Fresh Pond at $10100 \mathrm{yr}$ BP, next at No Bottom Pond, Rogers Lake, and Blood Pond at $9500 \mathrm{yr}$ BP, and lastly at Berry East Pond at 8900 yr BP (Figs. 2 and 3). The average age of the forb peak was $\sim 9300 \mathrm{yr}$ BP. The rise in forbs coincides with a region-wide decline in pine and increase in oak pollen and a subregional decline in hemlock pollen. Jack pine (Pinus banksiana) pollen also increases at Berry East Pond during this period. The forb period ends after $8000 \mathrm{yr}$ BP and is coincident with a regional increase in beech pollen (Fig. 2).

Peak values for charcoal influx at Blood and Berry East Ponds are higher between 10200 and 8500 yr BP than at any other time in the pre-European settlement Holocene (Fig. 3). Dunwiddie (1990) reported a similar pattern of charcoal: pollen ratios at No Bottom Pond. At Berry East Pond, organic content declines by $12-15 \%$ at ca. 9500 yr BP and then increases by $8-10 \%$ at ca. 7800 yr BP. Organic content at Blood Pond fluctuates considerably prior to $10000 \mathrm{yr} \mathrm{BP}$; however, levels remain relatively low and constant from 10000 to 8000 yr BP (Fig. 3). Fluctuations in organic content of $>5 \%$ may indicate substantial lake level fluctuations (Shuman 2003).

\section{Modern analogues for southern New England vegetation at 9000 yr BP}

To better understand the vegetation represented by 3.5-7\% forb pollen, we examined all pollen data for 500 yr BP from the Prairie Peninsula region of the Midwest (Minnesota, Wisconsin, Missouri, Illinois, Michigan, and Indiana) for analogues to the SNE early Holocene pollen assemblages (NAPD and Webb et al. 1983; see Plate 1). We chose this region because of its high density of pollen records and abundance of ragweed. Five sites (Volo Bog, Illinois; Clear Lake, Indiana; Hudson Lake, 


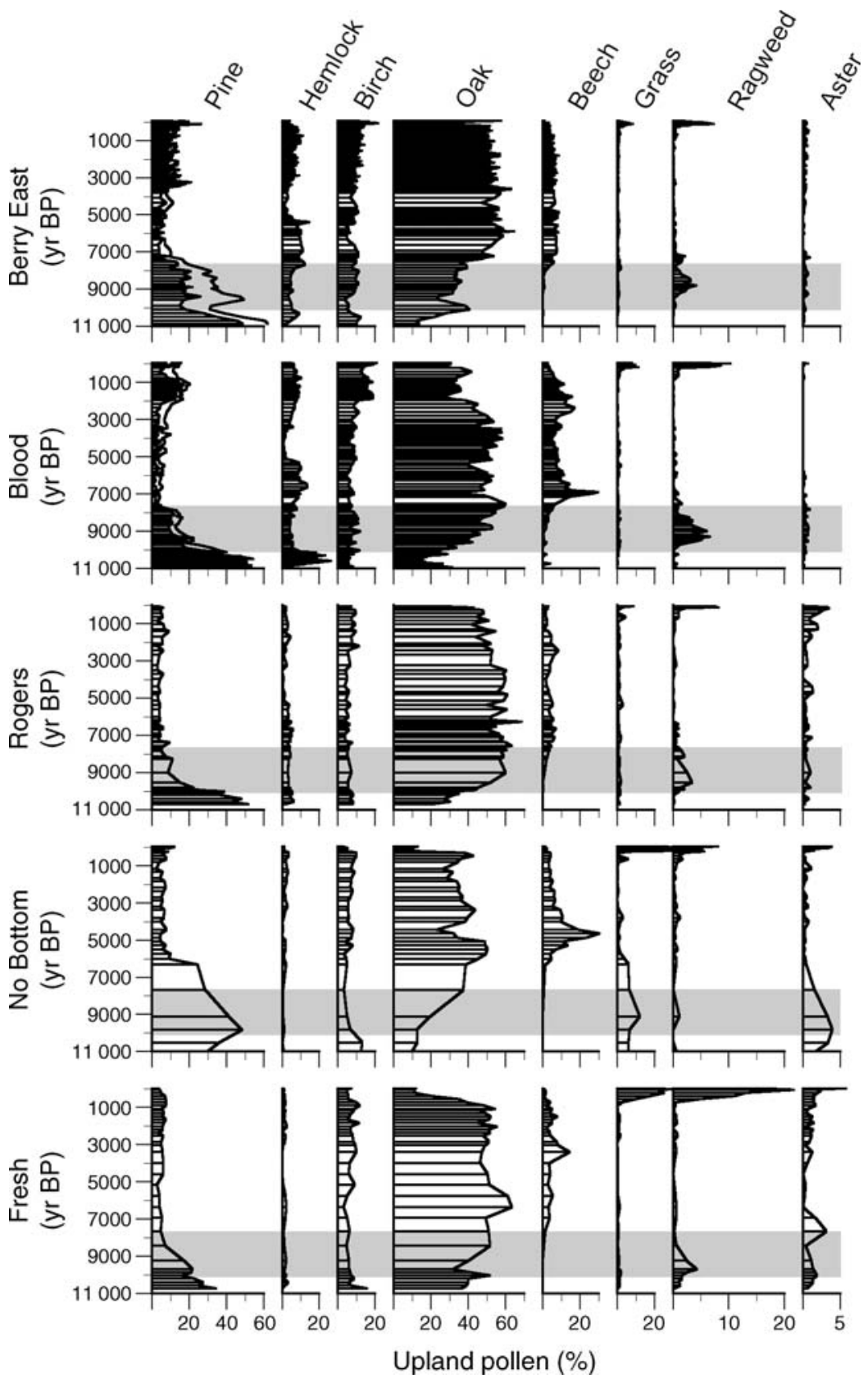

FIG. 2. Pollen percentage diagram of five southern New England forb sites: Blood Pond, Massachusetts; Berry East Pond, Massachusetts; Rogers Lake, Connecticut (Davis 1969); Fresh Pond, Rhode Island; and No Bottom Pond, Massachusetts (Dunwiddie 1990). The shaded area indicates the period from 10100 to $7700 \mathrm{yr}$ BP when the occurrence of forbs is $>3.5 \%$. For Berry East and Blood Pond pine, the outer (right-hand) line denotes total percentage of pine, the open area denotes jack pine type, and the solid (black) area denotes white pine type.

Indiana; Tamarack Creek, Wisconsin; and Blue Mounds Creek, Wisconsin) provided the closest match in terms of ragweed, total forb, and tree pollen percentages (Figs. 1 and 4). The New England sites had higher ragweed and shrub pollen percentages; lower goosefoot/amaranth, wormwood, grass, and tree pollen percentages; and similar aster and total forb values compared with the Midwestern sites (Fig. 4).
SCD values between the Midwestern sites at $500 \mathrm{yr}$ BP and the New England maximum forb assemblages were $\geq 0.15$ (data not shown). SCD values this high suggest that early Holocene SNE vegetation was not analogous to presettlement Midwestern vegetation (Gavin et al. 2004). SCD analysis between the five maximum forb assemblages and the entire records of all eight southeastern New England sites shows increasing dissimilarity 


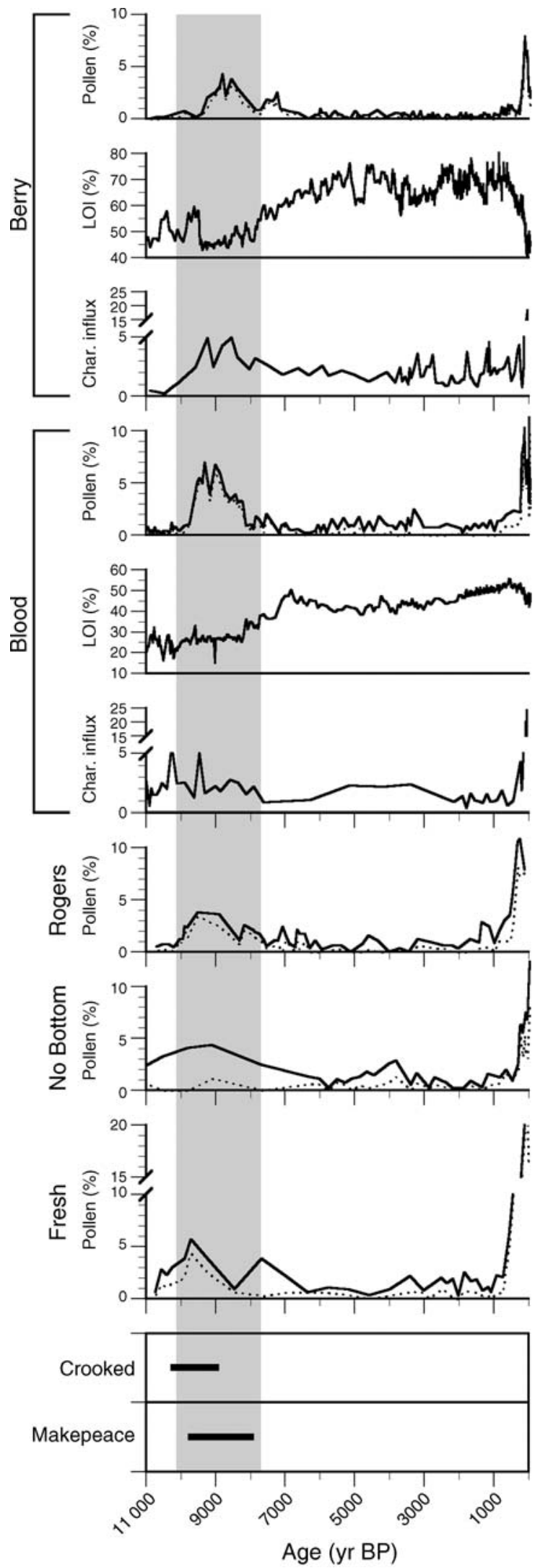

after 7000 yr BP (SCD > 0.05) (Fig. 5). SCD values remain high throughout the Holocene until the time of European settlement, when similarity increases at most sites. Comparison of the five maximum forb assemblages with two additional southeastern New England records (from HF) spanning the past 1500 years (Walden Pond, Massachusetts [Köster et al. 2005] and Bates Pond, Connecticut [Köster and Pienitz 2006]) yields even closer analogues: SCD values were $\leq 0.05$ at Walden Pond ca. AD 1720 (Fig. 5).

\section{Discussion}

The pollen record at five southern New England sites shows compelling evidence that open vegetation with ragweed and other forbs developed in the forested landscape of southern New England during the early Holocene. The temporal and spatial distribution of high values of these pollen taxa indicates that this vegetation developed in a restricted region in response to unique environmental conditions, namely a strong moisture deficit, and perhaps fire. These conclusions corroborate aspects of the initial interpretation made by Margaret Davis based solely on data from Rogers Lake. They also expand the understanding of openland vegetation during the Holocene and the conservation of modern assemblages in temperate forest regions.

The local occurrence of open vegetation in southern New England is indicated by the restricted distribution of high $(>3.5 \%)$ ragweed and forb pollen percentages. Long-distance delivery of this pollen, an interpretation proposed by H. E. Wright (1968), is ruled out by the lack of relationship between forb pollen abundance and (1) distance from the Midwestern prairies, or (2) basin size and the abundance of extraregional pollen in New England.

\section{Natural history of ragweed}

Interpretation of the structural characteristics, environmental setting, and possible mechanisms driving the development of ragweed and forb assemblages in this forest landscape is guided by an understanding of the ecological role of these taxa in modern and historical

FIG. 3. Summary of data from five southern New England (SNE) forb sites from this study and two SNE sites with lake level reconstructions: Crooked Pond, Massachusetts and Makepeace Cedar Swamp, Massachusetts (Newby et al. 2000, Shuman et al. 2001). Charcoal influx, organic content (\%), and forb percentages (solid line is the sum of four forb taxa [ragweed, other aster, sage, and goosefoot; dotted line represents ragweed] are presented for Blood Pond, Massachusetts, and Berry East Pond, Massachusetts. Forb percentages are similarly displayed for Rogers Lake, Connecticut (Davis 1969); Fresh Pond, Rhode Island; and No Bottom Pond, Massachusetts (Dunwiddie 1990). The solid bars for Crooked and Makepeace Ponds show the period when inferred water levels reached their lowest levels. The shaded area indicates the period from 10100 to $7700 \mathrm{yr}$ BP when forbs exceed 3.5\%. 


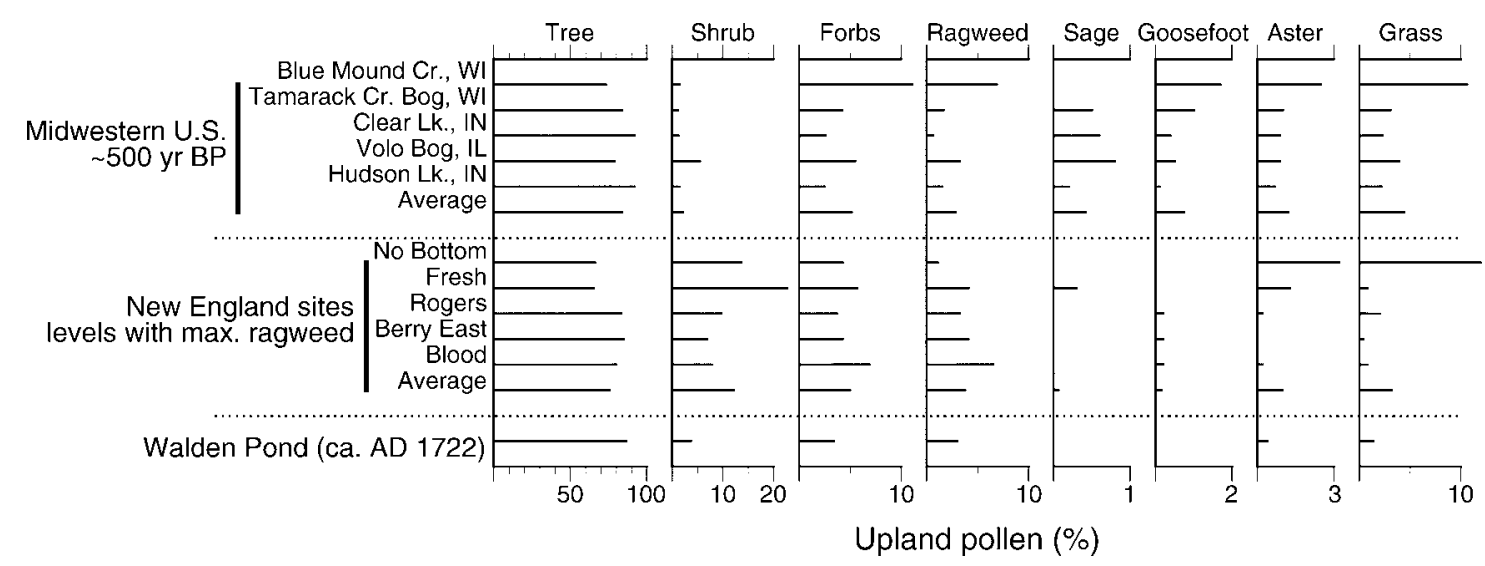

FIG. 4. Comparison of peak forb values and corresponding percentages of tree, shrub, and grass pollen from five southern New England sites at 9700-8800 yr BP with pollen data from five sites within the Prairie Peninsula Region, Midwestern USA, at 500 yr BP (North American Pollen Database). Data from the Walden Pond sample ca. AD 1722 are also included.

landscapes. Based on current distributions, three ragweed species could be represented in our pollen diagrams: Ambrosia artemisiifolia, A. trifida, and A. coronopifolia. The latter Midwestern species is uncommon and seldom flowers or sheds pollen (J. Almendinger, personal communication). A. trifida is uncommon in southern New England and associated with moist, alluvial soils (Harris 1975, Newcomb 1977). Floodplain soils are rare near our four sites, so we assume that $A$. artemisiifolia, the most common ragweed species across northeastern North America, was the species involved in the Holocene vegetation.

A. artemisiifolia is an annual that requires full or abundant sun for germination and robust growth, as well as frequent disturbance to persist with longer-lived, larger, and shade-tolerant forbs and grasses (Bazzaz 1974, Grimm 2001). Today ragweed is an abundant weed on fertile, agricultural, disturbed edge, and saline habitats such as abandoned lots, roadsides, and coastal areas (Bazzaz 1974; D. Mladenoff, personal communication). In pre-European landscapes, ragweed was most abundant in Midwestern prairies (Grimm 2001). There it occupied sites where the grass cover was chronically stressed, such as exposed ridgelines, mineral springs, floodplains, Indian encampments, buffalo wallows, and intensely grazed areas.

Historical and modern data indicate that in forested areas ragweed is restricted to open sites and is almost never found in the understory (Marks 1983; J. Almendinger, personal communication). Thus it is unlikely that it reached levels of $3-6 \%$ of the pollen sum in episodically disturbed forest. Rather, persistent ragweed pollen and dominance by arboreal taxa suggests a heterogeneous landscape dominated by forests but interrupted by open vegetation maintained by chronic disturbance. One scenario would include open savannas on ridge tops and southwest-facing, upper slopes of knolls where erosion, drought stress, and fire are common (cf. Grimm 2001; J. Almendinger, personal communication). A paucity of such topography and a paucity of fertile soils around Duck, Deep, Winneconnet, and No Bottom Ponds, which lie primarily in sandy, outwash plains, may explain the absence of high ragweed values at these sites (Heeley 1972); these ponds share similar arboreal vegetation and climate space to Rogers, Blood, Berry East, and Fresh Ponds (Fig. 1B). Southwest-facing knolls and ridge tops, as well as more fertile tilldominated soils, are characteristic of the landscapes surrounding these latter four ragweed sites (Heeley 1972, USGS 1982). Ragweed does grow in sandy soils, but it grows taller and is more common in heavy, fertile soils (Curtis 1959, Basset and Crompton 1975).

An alternative possibility is that ragweed and other forbs colonized broad lake margins exposed by water table fluctuations (J. Almendinger, personal communication). This scenario seems unlikely because regular lake level fluctuations over a 1000-1500 year period would be required for this annual to compete with perennials. Ragweed germinates in the spring before summer drawdown, further lessening the likelihood of this scenario (Grimm 2001).

\section{Other asters of the southern New England Coastal Plain}

Although ragweed is the dominant taxon in the southern New England forb assemblage, other asters dominate the assemblages at No Bottom Pond and at 7700 yr BP at Fresh Pond (Fig. 2). Many asters are perennials, most occupy open habitats, and few are characteristic of pond shores (Sorrie and Dunwiddie 1996). Thus high aster pollen percentages at No Bottom and Fresh Ponds also suggest substantial upland openings. Although we do not know which species of aster are represented in the early Holocene pollen records, characteristic species of open, coastal plain habitats today include: Aster linariifolius, A. dumosus, A. patens, A. solidagineus, A. paternus, Solidago nemoralis, Euthamia tenuifolia, E. graminifolia, Chrysopsis falcate, $C$. mariana (Sorrie and Dunwiddie 1996, Gould et al. 1998). 


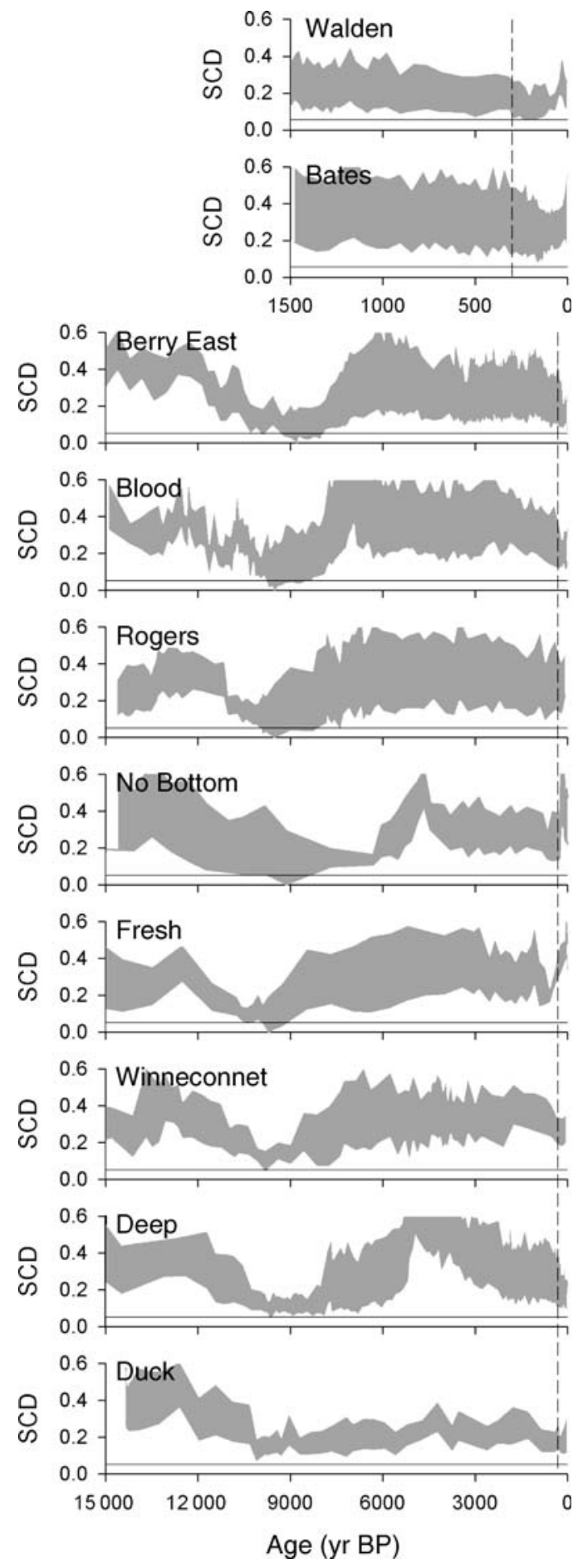

FIG. 5. Squared chord distance (SCD) values between the samples with maximum forb pollen percentage for Berry East Pond, Massachusetts; Blood Pond, Massachusetts; No Bottom Pond, Massachusetts; Fresh Pond, Rhode Island (Dunwiddie 1990); and Rogers Lake, Connecticut (Davis 1969) and the entire records of 10 southern New England pollen records. The shaded areas represent the range of values generated for each SCD comparison; lower SCD values reflect greater similarity between samples. The vertical dashed line refers to European settlement ca. AD 1700. The horizontal solid lines at 0.05 in

\section{Modern structural and compositional analogues to early Holocene southern New England sites}

Historical analogues support the interpretation that the early Holocene landscape in southern New England was composed of forest interspersed with patches of forbs in patterns that were structurally analogous to the early Colonial landscape of New England and the preEuropean vegetation on the northern edge of the Prairie Peninsula region (cf. Figs. 1C and 4). This interpretation is also supported by studies of pollen-vegetation relationships, which indicate that a $6.5 \%$ level of herbaceous pollen taxa (including grass) may reflect a forest landscape with $30 \%$ openlands in large (20-ha) patches (Sugita et al. 1999).

The increased similarity between the early Holocene assemblages and the southern New England samples after European settlement (as shown by SCD analysis) makes sense. During this early Colonial period large semipermanent pasture, crop, and hay fields were carved from the forest. SCD values are lowest at Walden Pond due to the dominance of oak-pine forest and low values of northern, mesic taxa like beech and hemlock.

The dissimilarity between the early Holocene New England vegetation and the Midwestern Prairie Peninsula sites at $500 \mathrm{yr}$ BP is readily interpretable. The Midwestern sites occupy soils that contrast sharply with those in New England in depth, texture, and base saturation. Midwestern vegetation assemblages also include hickory, which was absent in New England until the mid-Holocene, while they lack hemlock, and the Midwest has many forbs and grasses that are absent in New England (Fig. 4; Gleason and Cronquist 1991). Finally, shrubs were more prevalent at the early Holocene New England sites, particularly at Fresh and No Bottom Ponds (Fig. 4), than at the Midwestern sites. Exposure to windstorms and salt spray hinders the establishment of trees in recently disturbed New England coastal landscapes and favors heaths and other shrubs (Dunwiddie 1990). The Midwestern Prairie Peninsula at $500 \mathrm{yr}$ BP lacked coastal storms and salt spray (Curtis 1959), perhaps accounting for the lower shrub values.

\section{Environmental drivers of the early Holocene forb assemblages}

The development of weed-dominated openlands in a forested landscape requires two environmental drivers that operate and interact at different spatial and temporal scales: (1) a broad-scale climatic setting that reduces forest vigor and (2) frequent local disturbance. Although results from 18th century New England indicate that intense broad-scale disturbance alone can create openlands, there is considerable sedimentary

each graph refer to the threshold at or below which samples are considered analogous (Overpeck et al. 1985). See Methods for taxa used in SCD analysis. 


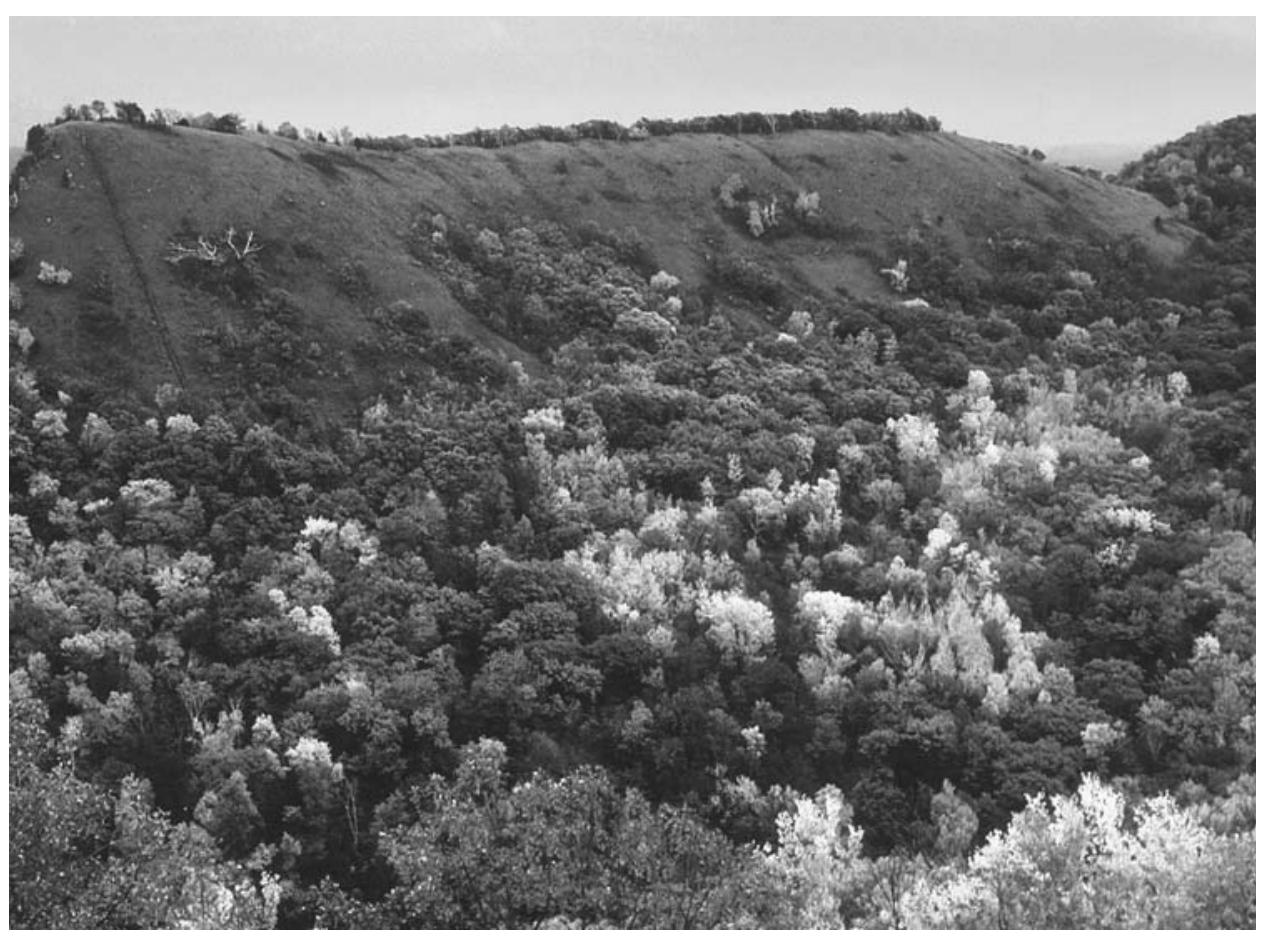

Plate 1. Modern bluff prairie in Minnesota (USA) and possible analogue for southern New England landscape at $9000 \mathrm{yr}$ BP. Photo courtesy of the Minnesota Department of Natural Resources.

evidence for broad-scale environmental change during the early Holocene in southern New England.

Our data provide compelling evidence for an interval of very dry climate between 10100 and $7700 \mathrm{yr}$ BP. Relatively drought-intolerant taxa (Thompson et al. 1999), including hemlock and white pine, decline at the beginning of this interval and remain low until after $8000 \mathrm{yr}$ BP, when hemlock increases with mesicdependent beech. Meanwhile, oak and jack pine, two of the most drought-tolerant taxa in eastern North America (Thompson et al. 1999), increase dramatically during this period. High forb percentages are also consistent with interpretations of a drier climate characterized by periodic drought (Grimm 2001, Clark et al. 2002). Organic content at Berry East reaches its lowest values during this period, with abrupt changes at 9500 and $7800 \mathrm{yr}$ BP suggesting changing water levels (Fig. 3; Shuman 2003). Lake-level reconstructions from southern New England corroborate these findings, as they show water levels reached their lowest levels between 10200 and 8000 yr BP (Fig. 3; Newby et al. 2000, Shuman et al. 2001).

\section{Disturbance}

The declining moisture balance presumably decreased tree vigor, regeneration, and growth; this in turn predisposed upland areas to support open vegetation. Nonetheless, frequent disturbance was still necessary to maintain ragweed's dominance in open habitats In addition to periodic drought (Grimm 2001, Clark et al.
2002), the most plausible disturbance processes include fire, large herbivores, and humans.

Relatively high charcoal peaks at Blood, Berry East, and No Bottom Ponds between 10200 and 8500 yr BP match well the expectation of increased fire activity with maximum summer insolation and decreased moisture availability (Fig. 3; Dunwiddie 1990, Berger and Loutre 1991). Higher charcoal also fits with a decline of pine and hemlock and an increase in oak and jack pine at these sites. Hemlock is an especially fire-sensitive species, and oaks, particularly the white oak group, are very fire resistant (Curtis 1959, Lynch and Clark 2002). Jack pine is also highly adapted to fire, as its cones typically require extreme heat and dryness to open (Curtis 1959). Vegetation of open forests with herbs produces a flammable fuel complex (cf. Rebertus and Burns 1997, Jeltsch et al. 2000); under these conditions fire may have helped establish and maintain ragweed at our sites.

The absence of sustained high charcoal values at Blood Pond indicates that other chronic disturbances may have been important in supporting ragweed abundance. Large browsers such as white-tailed deer (Odocoileus virginianus) interact with fire to maintain the dynamic structure and composition of many savannahs and openlands (Scholes and Archer 1997, Jeltsch et al. 2000). Abundant ragweed is also associated with prehistoric human land clearance, especially large permanent villages supported by horticulture (McLauchlan 2003). However, human populations in the early Holocene (Early Archaic period) of New England were 
small, dispersed, and seminomadic, and are unlikely to have been a major disturbance factor (Mulholland et al. 1998; E. Chilton, personal communication). One plausible human role was in the ignition of fires under highly flammable conditions in which the vegetation was prone to conversion to openlands.

\section{Conclusions and Relevance to the Openlands Debate}

Our results support and extend Margaret Davis's interpretation that high ragweed pollen ca. 9500 cal BP at Rogers Lake resulted from an early Holocene landscape with reduced forest cover. This vegetation occupied a substantial but geographically restricted area of southern New England dominated by oak and pine forests; similar vegetation did not occur again in the region until after European settlement. Indeed, the closest analogue to these pollen assemblages comes from eastern Massachusetts ca. AD 1720.

Across the Northeast, the early Holocene was characterized by rapid changes in climate and vegetation. The driest conditions in the past 15000 years were the dominant force promoting these savannah-like forest openings, but fire may have helped maintain the weedy, ragweed-dominated vegetation. This dynamic period closed with moister conditions and an increase in mesic forest, including shade-tolerant beech and hemlock. These results support the interpretation that openland vegetation did exist in the pre-European landscape as proposed by some authors (cf. Vera 2000). However, our data highlight the imprudence of generalizing any "original" Holocene vegetation structure of eastern North America without examining it in the context of a dynamic climate, which changed dramatically and often since deglaciation (Mayewski et al. 2004, Shuman et al. 2004). Given our findings that modern openlands have no detectable counterpart for the past 7000 years, we suggest that the interpretation and management of New England openlands should be focused on their European settlement origins; indeed, all important openlands in New England today were initiated or greatly expanded by Colonial agriculture. Nonetheless, these findings may have relevance for projections of future vegetation changes in southern New England, as several climate models forecast more arid conditions accompanying elevated $\mathrm{CO}_{2}$ levels during the next century (Rind et al. 1990).

\section{ACKNOWLEDGMENTS}

This study was supported by the National Science Foundation (DEB-0080592, DEB-9903792, DBI-0139495) and the A. W. Mellon Foundation, and is a contribution from the Harvard Forest Long Term Ecological Research program. Special thanks to Brian Hall for work on figures. The manuscript benefited from the comments of T. Webb and an anonymous reviewer and from discussions with M. Lindbladh, B. Patterson, G. Motzkin, P. Marks, and the Harvard Forest Lab group. Insightful perspectives on the modern and historical role of ragweed were provided by $\mathbf{J}$. Almendinger and $\mathrm{D}$. Mladenoff. Helpful discussions on the history and conservation value of openlands in Europe and North America were enjoyed with R. Bradshaw, M-J. Gaillard, F. Mitchell, K. Kirby, and R. Askins. D. R. Foster thanks H. E. Wright and M. B. Davis for bringing the early Holocene dynamics of ragweed to his attention in 1981 .

\section{Literature Cited}

Askins, R. A. 2000. Restoring North America's birds. Yale University Press, New Haven, Connecticut, USA.

Bassett, I. J., and C. W. Crompton. 1975. The biology of Canadian weeds. 11. Ambrosia artemisiifolia L. and $A$. psilostachya DC. Canadian Journal of Plant Science 55: 463-476.

Bazzaz, F. A. 1974. Ecophysiology of Ambrosia artemisiifolia: a successional dominant. Ecology 55:112-119.

Berger, A., and M. F. Loutre. 1991. Insolation values for the climate of the last 10 million years. Quaternary Science Reviews 10:297-317.

Boose, E. R., K. E. Chamberlin, and D. R. Foster. 2001. Landscape and regional impacts of hurricanes in New England. Ecological Monographs 71:27-48.

Bradshaw, R. H. W., G. E. Hannon, and A. M. Lister. 2003. A long-term perspective on ungulate-vegetation interactions. Forest Ecology and Management 181:267-280.

Braun, E. L. 1950. Deciduous forests of eastern North America. Blackiston, Philadelphia, Pennsylvania, USA.

Clark, J. S., E. C. Grimm, J. J. Donovan, S. C. Fritz, D. R. Engstrom, and J. E. Almendinger. 2002. Drought cycles and landscape responses to past aridity on prairies of the northern Great Plains, USA. Ecology 83:595-601.

Cogbill, C. V., J. Burk, and G. Motzkin. 2002. The forests of presettlement New England, USA: spatial and compositional patterns based on town proprietor surveys. Journal of Biogeography 29:1279-1304.

Cronon, W. 1984. Changes in the land: Indians, colonists, and the ecology of New England. Hill and Wang, New York, New York, USA.

Curtis, J. T. 1959. The vegetation of Wisconsin. University of Wisconsin Press, Madison, Wisconsin, USA.

Davis, M. B. 1969. Climate changes in southern Connecticut recorded by pollen deposition at Rogers Lake. Ecology 50: 409-422.

Davis, M. B. 1983. Holocene vegetational history of the Eastern United States. Pages 166-181 in Late-Quaternary environments of the United States. Volume 2: The Holocene. University of Minnesota Press, Minneapolis, Minnesota, USA.

Dunwiddie, P. W. 1990. Postglacial vegetation history of coastal islands in southeastern New England. National Geographic Research 6:178-195.

Foster, D. R. 2004. The physical and biological setting for ecological studies. Pages 19-31 in D. R. Foster and J. D. Aber, editors. Forests in time. Yale University Press, New Haven, Connecticut, USA.

Foster, D. R., B. Hall, S. Barry, S. Clayden, and T. Parshall. 2002. Cultural, environmental and historical controls of vegetation patterns and the modern conservation setting on the island of Martha's Vineyard, USA. Journal of Biogeography 29:1381-1400.

Foster, D. R., and G. Motzkin. 2003. Interpreting and conserving the openland habitats of coastal New England: insights from landscape history. Forest Ecology and Management 185:127-150.

Gavin, D. G., W. W. Oswald, E. R. Wahl, and J. W. Williams. 2004. A statistical approach to evaluating distance metrics and analog assignments for pollen records. Quaternary Research 60:356-367.

Gleason, H. A., and A. Cronquist. 1991. Manual of vascular plants of the Northeastern United States and adjacent Canada. New York Botanical Garden, Bronx, New York, USA. 
Gould, L. L., R. W. Enser, R. E. Champlin, and I. H. Stuckey. 1998. Vascular flora of Rhode Island. Rhode Island Natural History Survey, Kingston, Rhode Island, USA.

Grimm, E. C. 2001. Trends and palaeoecological problems in the vegetation and climate history of the Northern Great Plains, USA. Biology and Environment: Proceedings of the Royal Irish Academy 101B(1-2):47-64.

Harris, S. K. 1975. A flora of Essex County, Massachusetts. Peabody Museum of Salem, Salem, Massachusetts, USA.

Heeley, R. W. 1972. Surficial geologic map of Massachusetts. 1:510,000. Water Resources Research Center Publication 31. University of Massachusetts, Amherst, Massachusetts, USA

Jeltsch, F., G. E. Weber, and V. Grimm. 2000. Ecological buffering mechanisms in savannahs: a unifying theory of long-term tree-grass coexistence. Plant Ecology 161:161-171.

King, J. E. 1981. Late Quaternary vegetational history of Illinois. Ecological Monographs 51:43-62.

Kirby, K. J. 2004. A model of a British forest-landscape driven by large herbivore activity. Forestry 77:406 420 .

Köster, D., and R. Pienitz. 2006. Seasonal diatom variability and paleolimnological inferences - a case study. Journal of Paleolimnology 35:395-416.

Köster, D., R. Pienitz, B. B. Wolfe, S. Barry, D. R. Foster, and S. S. Dixit. 2005. Paleolimnological assessment of humaninduced impacts on the nutrient balance of Walden Pond (Massachusetts, USA) during the last three centuries using diatoms and stable isotopes. Aquatic Ecosystem Health and Management 8:117-131.

Lynch, J. A., and J. S. Clark. 2002. Fire and vegetation histories in the southern Appalachian Mountains: the historical importance of fire before and after European/American settlement. A report submitted to the George Washington and Jefferson National Forest, Roanoke, Virginia, USA.

Marks, P. L. 1983. On the origin of the field plants of the northeastern United States. American Naturalist 122:210228.

Mayewski, P. A., et al. 2004. Holocene climate variability. Quaternary Research 62:243-255.

McLauchlan, K. K. 2003. Plant cultivation and forest clearance by prehistoric North Americans: pollen evidence from Fort Ancient, Ohio, USA. Holocene 13:557-566.

Mitchell, F. J. G. 2005. How open were European primeval forests? Hypothesis testing using palaeoecological data. Journal of Ecology 10:1-10.

Motzkin, G., and D. R. Foster. 2002. Grasslands, heathlands, and shrublands in coastal New England: historical interpretations and approaches to conservation. Journal of Biogeography 29:1569-1590.

Mulholland, M. T., C. Donta, and T. L. Arcuti. 1998. Community archaeological reconnaissance survey of Chilmark, Massachusetts. University of Massachusetts Archaeological Services, Report UM-255. Environmental Institute, University of Massachusetts, Amherst, Massachusetts, USA.

Newby, P. C., P. Killoran, M. Waldorf, B. N. Shuman, T. Webb, III, and R. S. Webb. 2000. 14,000 years of sediment, vegetation, and water level changes at Makepeace Cedar Swamp, southeastern Massachusetts. Quaternary Research 53:352-368.

Newcomb, L. 1977. Newcomb's wildflower guide. Little, Brown, Boston, Massachusetts, USA.

Overpeck, J. T., T. Webb, III, and I. C. Prentice. 1985. Quantitative interpretation of fossil pollen spectra: dissimilarity coefficients and the method of modern analogs. Quaternary Research 23:87-108.

Parshall, T., and D. R. Foster. 2002. Fire in New England. Journal of Biogeography 29:1305-1317.
Patterson, W. A., III, and A. E. Backman. 1988. Fires and disease history of forests. Pages 603-632 in B. Huntley and T. Webb, III, editors. Vegetation history. Kluwer Academic, Dordrecht, The Netherlands.

Patterson, W. A., III, and K. E. Sassaman. 1988. Indian fires in the prehistory of New England. Pages 107-135 in G. P. Nicholas, editor. Holocene human ecology in northeastern North America. Plenum, New York, New York, USA.

Pyne, S. J. 1982. Fire in America: a cultural history of wildland and rural fire. University of Washington Press, Seattle, Washington, USA

Rebertus, A. J., and B. R. Burns. 1997. The importance of gap processes in the development and maintenance of oak savannahs and dry forests. Journal of Ecology 85:635-645.

Rind, D., R. Goldberg, J. Hansen, C. Rosenzweig, and R. Ruedy. 1990. Potential evapotranspiration and the likelihood of future drought. Journal of Geophysical Research-Atmospheres 95:9983-10004.

Scholes, R. J., and S. R. Archer. 1997. Tree-grass interactions in savannahs. Annual Review of Ecology and Systematics 28: 517-544.

Shuman, B. 2003. Controls on loss-on-ignition variation in cores from two shallow lakes in the northeastern United States. Journal of Paleolimnology 30:371-385.

Shuman, B., J. Bravo, J. Kaye, J. A. Lynch, P. Newby, and T. Webb, III. 2001. Late Quaternary water-level variations and vegetation history at Crooked Pond, Southeastern Massachusetts. Quaternary Research 56:401-410.

Shuman, B., P. Newby, Y. Huang, and T. Webb, III. 2004. Evidence for the close climatic control of New England vegetation history. Ecology 85:1297-1310.

Sorrie, B. A., and P. W. Dunwiddie. 1996. The vascular and non-vascular flora of Nantucket, Tuckernuck, and Muskeget Islands. Massachusetts Audubon Society, Nantucket, Massachusetts, USA.

Sugita, S. 1993. A model of pollen source area for an entire lake surface. Quaternary Research 39:239-244.

Sugita, S., M. J. Gaillard, and A. Brostrom. 1999. Landscape openness and pollen records: a simulation approach. Holocene 9:409-421

Svenning, J. C. 2002. A review of natural vegetation openness in north-western Europe. Biological Conservation 104:133148.

Thompson, R. S., K. A. Anderson, and P. J. Bartlein. 1999. Atlas of the relations between climatic parameters and the distribution of important trees and shrubs in North America. U.S. Geological Survey Professional Paper 1650-A, B, U.S. Geological Survey, Denver, Colorado, USA.

USGS. 1982. 1:25,000 scale metric topographic maps: Massachusetts. U.S. Geological Survey, Washington, D.C., USA.

Vera, F. W. M. 2000. Grazing ecology and forest history. CABI, Wallingford, UK.

Vickery, P. D., and P. W. Dunwiddie. 1997. Introduction. Pages $1-13$ in P. D. Vickery and P. W. Dunwiddie, editors. Grasslands of northeastern North America. Massachusetts Audubon Society, Lincoln, Massachusetts, USA.

Webb, T., III, E. Cushing, and H. E. Wright, Jr. 1983. Holocene changes in the vegetation of the Midwest. Pages 142-165 in Late-Quaternary environments of the United States. Volume 2: The Holocene. University of Minnesota Press, Minneapolis, Minnesota, USA.

Wright, H. E. 1968. The roles of pine and spruce in forest history of Minnesota and adjacent areas. Ecology 49:937955.

\section{APPENDIX}

A list of the sites mapped in Fig. 1 (Ecological Archives E087-153-A1). 